\title{
Ceausescu's population policy: a moral or an economic choice between compulsory and voluntary incentivised motherhood?
}

Florin S. Soare, University of Bucharest and Institute for the Investigation of Communist Crimes and the Memory of the Romanian Exile (IICCMER)

\begin{abstract}
The purpose of this paper is to explain why, in 1966, the Romanian leadership adopted a wholly restrictive pronatalist policy, based on the strict limitation of abortion, instead of one based on socioeconomic incentives to families, as suggested by technocrats. Previous literature shows disagreement on whether the choice was motivated by moralistic or economic considerations. In order to find an answer to this question, hundreds of pages of archival material unpublished so far have been analysed, including the minutes of the Central Committee of the Communist Party, statistics, documents identified in the Ministry of Health Archive, and the technical reports that were on the table at the time of the decision. The conclusion of this study, drawn on the basis of these documents, indicates that at the time of 1966, regardless of the suggestions of the technocrats, a decision had already been taken by Ceausescu himself. This decision was influenced directly by economic considerations, namely the wish to obtain the maximum pronatalist effect at a minimum budgetary cost.
\end{abstract}

\section{JEL Classification}

J10; J13; J18

\section{Keywords}

Pronatalist policy; abortion; Romanian Communist Party; birth rate 


\section{Introduction}

For almost two decades, the Ceausescu regime applied a pronatalist policy, the character of which was greatly influenced by a limited vision of the problems of the population by the political leaders, who had a traditionalist vision of the family and its role, and a tendency to look for solutions in the Stalinist model. In Communist Romania, the enactment of restrictive abortion legislation emerges after 1966 as a special kind of intervention of the state in the private life of the individual, as a way to bolster its control over the population.

The ban on abortion, as an attempt to control fertility and influence the natural movement of the population, was a widely popular measure in (but not restricted to) totalitarian systems, being one of the lynchpins of population policy. In the majority of cases, this represented only one of the components of a demographic programme. In general, we can identify three pillars of a policy meant to increase the number of births: (1) the restriction of abortion, (2) the use of propaganda, and (3) economic and social measures designed to stimulate births. The prevalence of one of the three, or rather, of the first two, defines a regime as restrictive and coercive, centred on the drastic limitation of abortion.

Why did Romania implement such an aggressive population policy? Why did the prohibition of abortion constitute the central element of this policy? These questions have multiple potential answers, which will be analysed in this article, beginning with economic and ideological motivations and the way in which these influenced the restrictive character of the legislation adopted after 1966. The study thus addresses two different questions. The first tries to find explanations for the ambitious expansionary nature of Romania's demographic policy, in general. The second question tries to make sense of the overwhelmingly restrictive nature of the policies implemented.

In order to answer these questions, the article presents an account of the way in which Romania's 1966 pronatalist legislation was adopted. It also discusses the general characteristics of this population policy, and presents some of the policy alternatives that were debated at the time. All these aspects are analysed on the basis of source material coming from public discourse and the internal debates of the Romanian Communist Party (RCP), as well as consultations with medical specialists on the issues of demography and natalism.

The article presents the two main pronatalist options that were considered at the time: on the one hand, the technocratic option, contained in two documents elaborated by the Ministry of Health; on the other hand, the political vision of the Executive Committee of the Central Committee of the RCP resulting from its two meetings held in August and September 1966. It also describes the consultation with the medical staff that took place on 20 September 1966 in order to ensure their consent and the legitimacy of the final decision.

In contrast to the existing literature, which has focused on other aspects, such as the negative consequences of the policy, this article tries to explain the motivations of political leaders who were responsible for the decision, and their reasons for rejecting the technocratic proposals presented by medical specialists. The concluding part of the study highlights the role played by economic considerations in the population policy choice of the Ceausescu regime, by comparing the budgetary impact in terms of expenditure and revenue of both the technocratic and political solutions.

\section{Historiography of the subject}

The theme of pronatalist policies of contemporary states is still quite rife with controversy, being highly debated in Romanian and Western historiographies. Scientific research devoted to the topic, both in Romania and in the West, is 
generous. A large number of studies and volumes by historians, sociologists, and demographers were published after 1989, the majority of which focused on the negative demographical, medical and social outcomes of the post-1966 pronatalist policy. They detail the high level of maternal and infant mortality, the physical and mental trauma of women, the abandonment and institutionalisation of children, the appearance of congenital diseases among them, and the appearance and proliferation of AIDS among institutionalised children (Hord et al 1991; Johnson 1991; Kivu 1993; Kligman 1992; Şerbănescu et al 1995). Raw data on the pronatalist policy, studies on social memory, oral history, gender studies are supplied by Anton (2007; 2009), Baban (1999; 2000), Bărbulescu (1998), Betea (2004), Bodeanu (2002) and Pop-Eleches (2006, 2010).

Gail Kligman (1998) offers the first complex synthetic work dedicated to the demographic policies of the Ceausescu regime. Kligman's work constitutes a documentary analysis of the pronatalist policies of the regime from a number of perspectives: legislation and its application, communist propaganda, the manner in which the entire society was constrained to submit to the new rules, and the social problems which beset Romania at the beginnings of the 1990s as a direct consequence of those measures. The work has a few caveats, the most important of which being related to the scarcity of archival documentation, which is easily explainable due to restricted access in the 1990s. In recent years, the debate in the field of historiography regarding the population policy of the Ceausescu regime has become more nuanced due to the opening of the archives of some communist state institutions. The discussion has moved from consequences to causes, with a focus on understanding the implementation of pronatalist legislation. Researchers such as Pălăşan (2009), Doboş (2012), Jinga and Soare (2011) have attempted to demonstrate the exceptional character of the post-1966 Romanian population policy.

The current study brings a new perspective on this problem, on the basis of sources obtained from the archive of the Ministry of Health and the Romanian Communist Party, documents that greatly clarify the motivation of the political leadership to opt for a restrictive policy, as well as the arguments against the adoption of the technocratic initiatives.

\section{Justification of Romanian pronatalism}

Economic arguments. In 1965, Romania was in demographic decline, manifested especially through the decline in births, a situation which was similar to that in the majority of Central- and Eastern-European states. According to the Census of 15 March 1966, Romania had a population of only 19,105,056 inhabitants, ${ }^{1}$ and births were only at a rate of 14.6 percent, an indicator that 'did not even ensure the simple reproduction of the population, that is one female child for each woman in her fertility period from 15 to 49 years of age'.

\footnotetext{
${ }^{1}$ Comunicat cu privire la rezultatele preliminare ale recensământului populaţiei şi locuinţelor din 15 martie 1966 [Statement on preliminary results of population and housing census of March 15, 1966] Arhivele Naţionale Istorice Centrale (A.N.I.C.), fond C.C. al P.C.R., Secţia Organizatorică, dosar 30/1966, f. 1 .

${ }^{2}$ A.N.I.C., fond C.C. al P.C.R., Secţia Cancelarie, dosar 101/1966, f. 106.
} 
Figure 1. Total fertility rate (TFR) in Romania, 1956-1966

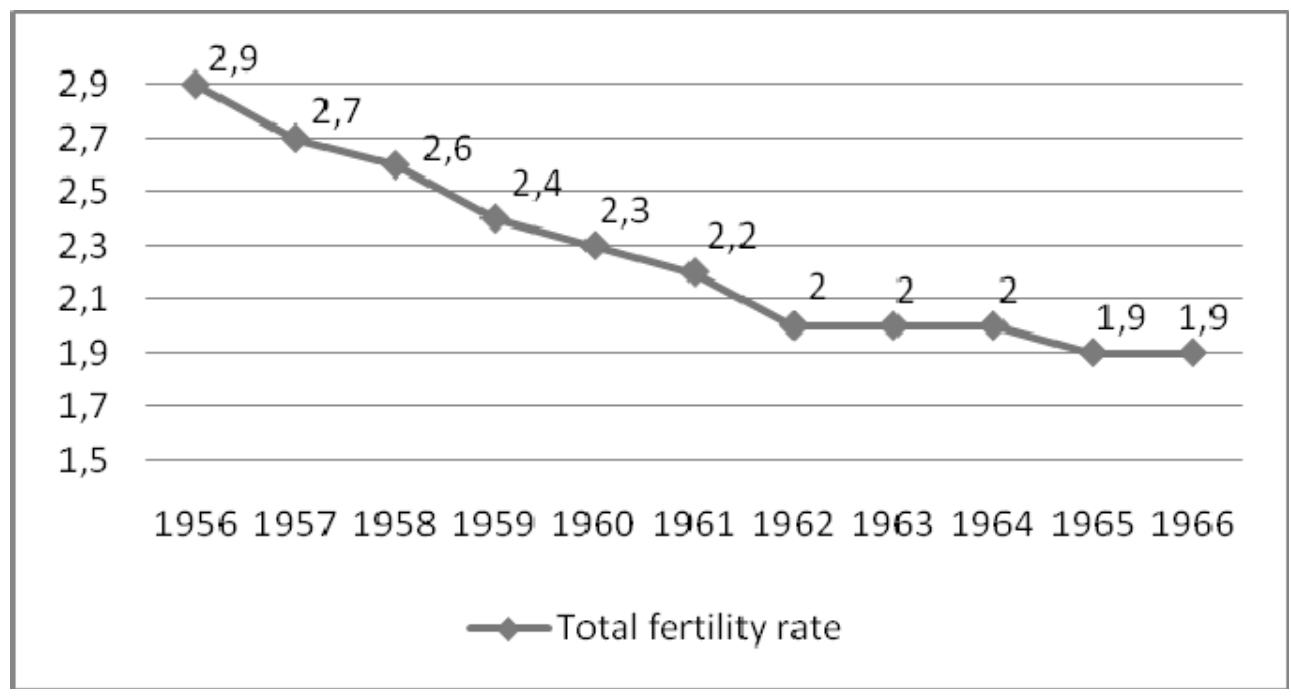

Source: National Institute of Statistics, Romanian Demographic Yearbook, 2006: 120.

Demographic considerations notwithstanding, the new regime that ruled over Bucharest was genuinely worried about the obstacles this would pose for the construction of socialism, for industrial development, due to the existence of a population 'with a structure based on old-age groups'. Even during the existence of the regime, Mary Ellen Fischer (1985: 125) argued for the economic motivation for the adoption by the regime of a coercive policy designed to raise birth-rates. The economic argument rests in the Stalinist dogma, according to which more people could generate a stronger economy. The need for work-force became more poignant in the 1950s, due to the ample industrialisation process of Gheorghiu Dej, intensified further after his refusal of the Soviet economic integration plans. ${ }^{3}$

From an economic standpoint, the regime's population policy was centred on the expansion of the work-force. This was realised in the 1950s through the expansion of the female work-force. Once these reserves were exhausted, Ceausescu's plans became centred on the encouragement of population growth by means of pronatalist policies. Thus, we may admit the fact that one of the main reasons behind the adoption of a pronatalist policy was the need to create and maintain a supplementary work-force, necessary for the industrialisation process. The regime's propaganda constantly linked population policy to the economic development of Romania, population policy being considered to be 'an integral part of the economic and social policy of the state' (Pavelescu, 1977: 8). An interdependency of economic and demographic growth was invoked: 'the country's economic growth cannot be envisioned without demographic growth, without complex measures to raise birth rates and maintain them at a relatively high level' (Trebici, 1971: 26).

\footnotetext{
${ }^{3}$ At the beginning of the 1960s, the Soviet Union proposed a project of economic organisation in Eastern Europe that sought the specialisation of the economies of these countries on the production of certain items (the E.B. Valev plan). Romania was to become a predominantly agricultural country. Gheorghiu Dej understood this plan as one that undermined his authority, and he rebuffed it, and intensified the industrialisation process even more by developing common projects with Yugoslavia, and bought Western technological developments. In this context, the need for a sufficient workforce became essential (see Retegan, 2002).
} 
Figure 2. The Dynamics of the Labour Movement in Industry by gender in Romania $1957-1965$ (in thousands)

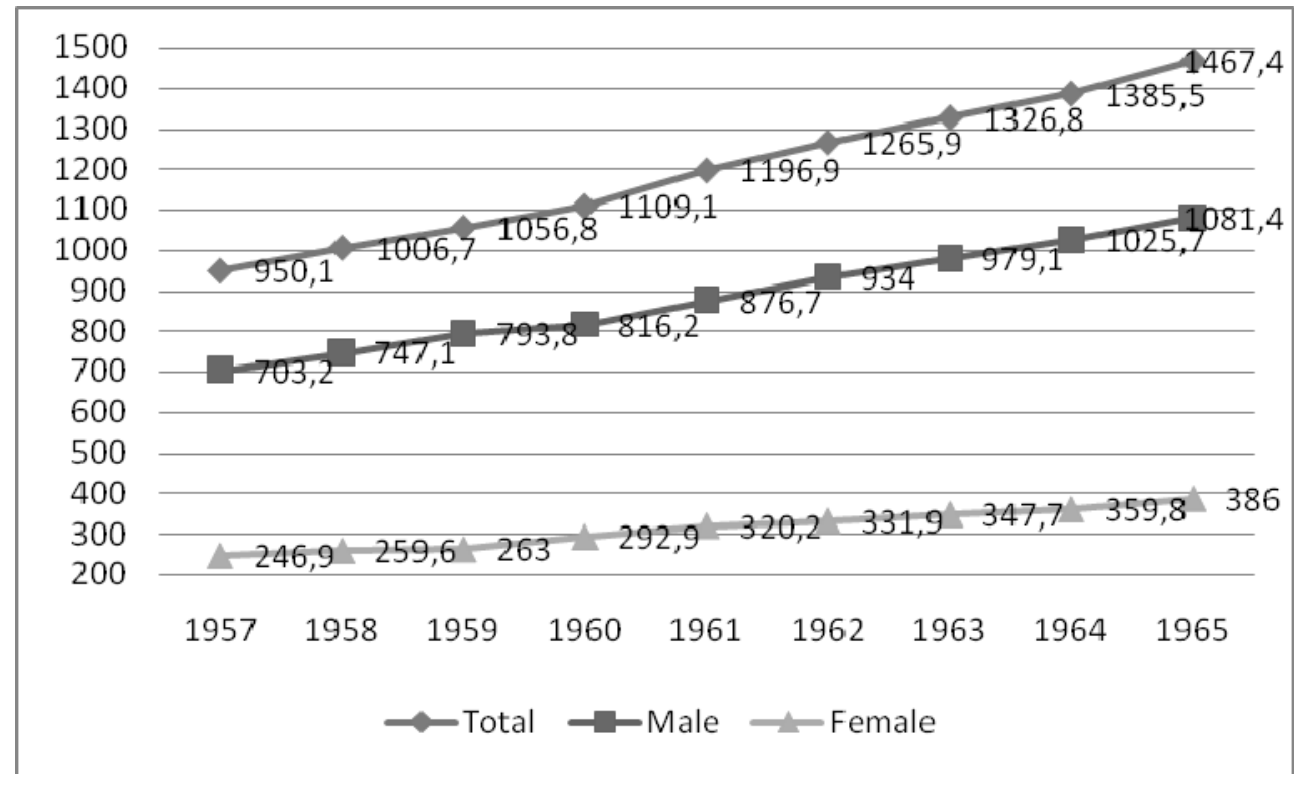

Source: National Institute of Statistics, Romanian Statistic Yearbook, 1957-1966.

In the planned economies of the communist states, control over the population was considered to be highly necessary. According to communist ideology, population has a triple role: work-force, a subject of income, and a consumer of the goods that were created, so the state 'has to provide the policies for the population, in the same way it plans the national economy, in order to respond to the overall interests of society' (Trebici, 1971: 39). The discussion was permanently centred on the way in which this intervention should be done. In the report of the Committee on the Study of the Measures designed to Improve the National Birth Rates, presented in the session of the Executive Committee of the Central Committee of the RCP of August 1966 (the basis for the preliminary discussion on the adoption of pronatalist policies), it was stated that the entire set of measures destined to raise birth rates was determined in an objective manner by the need to ensure an adequate work force for the development of the Romanian economy, especially after $1980 .{ }^{4}$ In the RCP manifesto of 1974, the sustained growth of the population was thought to be the essential factor for the dynamism and the productive strength of society. The target was the attainment of an active work-force of 11.5 million persons by the year 1990 (Partidul Comunist Român, 1975: 92).

To the above-mentioned economic considerations, we must add political and ideological arguments. Referring to McIntosh (1982: 277), there are three types of state attitudes toward population: population perceived as being linked to national power, the role that population plays in the productive economy, and the role of the state in society. According to this scheme, we may affirm there is a close link between population and the power of the state, as the number and quality of people greatly determines the power of the state and the policies that it promotes at a national and international level.

The same hypothesis was put forward by Adrian Cioroianu, who attempted to link Nicolae Ceausescu's admiration for the French president, Charles de Gaulle, and the latter's population policy, generated by his obsession for the growth of the population (Cioroianu, 2012). A second model for the population policy of

\footnotetext{
${ }^{4}$ Studiu privind situaţ̧ia natalităţii din Republica Socialistă România şi măsuri de redresare a natalităţii din ţara noastră, A.N.I.C., fond C.C. al P.C.R., Secţia Cancelarie, dosar 101/1966, f. 108.
} 
Bucharest was undoubtedly the Soviet model. The Soviet answer to the birth rate issue is exceptionally important for understanding the measures adopted by the Ceausescu regime. The Stalinist model of the 1930s-40s was a source of inspiration, from its severe restriction of abortions and the limitations it imposed on divorces, to its large-scale use of pronatalist propaganda (Goldman, 1993).

In his volume of interviews entitled 'I was a carver of chimeras', Dumitru Popescu states that one of the main reasons why Ceausescu opted for his population policy was his complex regarding 'the withering of the territory he ruled' (Popescu, 1993: 307). Certainly, 'solving the population problem', represented one of the major objectives of his 23 years of pronatalist policy. The reason was, as mentioned in the Health Ministry report above, the need to maintain a certain place of his country, among all the countries of the world. ${ }^{5}$ The promotion of a policy that would increase the number of inhabitants served, at the same time, the nationalist goals of the Ceausescu regime, visible during the proceedings of the World Population Conference in Bucharest in 1974, during which population was referred to as 'a component of national power', and 'population policy' became an 'attribute of state sovereignty' (Ceausescu 1981).

In 1966, the regime showed concern about the possibility of only limited growth of the population (21.5 million people projected for the year 2000), while at the same time, a 53 percent growth rate was recorded for the developed states of the world. ${ }^{6}$ The authors of the study entitled '... On the situation of natality...' argued that, in order for the same rate to be achieved in Romania, a 23 percent rise in births would be necessary so that the population would reach 29 million by the year 2000. In 1966, Romania had a population numbering 19,083,443, and a natural population growth of 6.1 percent. The comparison to the developed states, which systematically appears in Nicolae Ceausescu's discourse, was not the only argument, but, especially after 1968, it was coupled with the obsession of a foreign threat. $^{7}$

Demographic growth was beginning to be seen as a source of military power, as it was directly related to the number of persons that the state would be able to mobilise in the case of war. The problem was highlighted in the context of the elaboration of a new defence doctrine. 'The doctrine of the fight of the entire people' and the role of demography for the security of the nation were constantly espoused by Ceausescu (1970: 300) as: '...an anti-imperialist war, a war of defence cannot be anything but a popular war, and the victory would be obtained not only on the battlefront but through the general engagement of the entire people.'

Beyond this line of thought, which gained strength during the 1970s, in 1966 the political leadership did not view the problem of population in its complexity, but sought simple solutions that were cost-effective and produced quick results. This may be the reason for the moral arguments that were called for during the sessions of the Executive Committee of the Party, prior to the adoption of the Decree 770 of 1966. 'Moral traditionalism', invoked during the session, cannot be excluded as one

\footnotetext{
${ }^{5}$ A.N.I.C., fond C.C. al P.C.R., Secţia Cancelarie, dosar 101/1966, f.108.

${ }^{6}$ To date, I have been unable to identify the UN study to which the document (Studiu privind situaţia natalităţii) refers. Therefore we cannot regard the data used by the political establishment in 1966 in Bucharest as reliable when discussing the necessity of implementing a new programme for the increase of the birthrate. See Studiu privind situaţia natalităţii din Republica Socialistă România şi măsuri de redresare a natalităţii din ţara noastră, A.N.I.C., fond C.C. al P.C.R., Secţia Cancelarie, dosar 101/1966, f. 104.

7 Several members belonging to Ceausescu's inner executive circle, among whom the ex-Foreign Minister between 1978-1985, Stefan Andrei, agree with the fact that the communist leader was genuinely concerned about a Soviet military intervention, both during the year of 1968, and even after towards the end of the regime (Betea 2011).
} 
of the considerations for banning abortion, but this represented, alongside the medical argument, only the pretext, not the reason for implementing Ceausescu's pronatalist plan. One must not forget that the severe limitation of abortions was but one of the component elements of the global policy of the regime. It is difficult to state that moral arguments took precedence over concrete political and economic motivations.

In 1966, Romania was in full demographic transition, a process which marks the passing from a demographic regime marked by high numbers of births and mortality, to one defined by low birth rate and mortality. The phenomenon was due to a number of socio-economic factors (industrialisation, urbanisation, the integration of women into the workforce, the improvement of medical services), demographic factors (the drop in the number of marriages, the rise in the number of divorces, the rise in the number of abortions), cultural and educational factors (the rise of the duration of obligatory schooling, the rise in the quality of life, the drop in influence of the religious factor), legislative factors (the introduction of liberal legislation concerning divorces and abortions), etc. As far as the demographic transition is concerned, Romania was a few steps behind even in relation to its Eastern European neighbours, due to the lateness in the onset of modernity: the low degree of urbanisation, industrialisation, the improvement of living standards, the improvement of hygiene and health provisions, and so forth (Trebici, 1981). All these elements were cast aside by those who decided Romania's population policy.

\section{The technocratic option: 'The study on the situation of natality in the Romanian Socialist Republic'}

The regulation of abortions, as a central element of pronatalist policy, did not come about at once. The initiative did not come from the political leadership, as the specialist literature of the topic shows, but from a committee that studied fertility and sterility. This Committee, functioning under the auspices of the Health Ministry, grouped specialists from the fields of medicine, demography, genetics, which in 1965 put together some material presenting Romania's demographic evolution, the reasons for the drop in birth rates (socio-economic, socio-cultural, demographic), and made a demographic projection up to the year 2000. It also proposed a number of socio-economic, cultural, and sanitary-educational measures for the improvement of the natural growth of the population.

This document was the first one which put forward the need to limit the number of abortions through medical and legal measures. The proposals were based on the consultation of specialists of the Ministry of Health and the Council for Obstetrics and Gynaecology. The material suggested the implementation of urgent measures for halting declining birth rates. Socio-economic and cultural, educational and sanitary measures were proposed..$^{9}$

It was for the first time since 1957 that a stricter regulation of abortions was proposed. The initiative came from within the Ministry of Health, and did not envision changing existing legislation, but the introduction of new instructions for applying Decree 463 of 1957, which would limit abortions, with a generous list of exceptions (medical and socio-medical), and also the promotion of sexual and contraceptive education among the population. Besides protecting the health of women, the measure had a pronounced demographic character, underlined by the

\footnotetext{
${ }^{8}$ Ministerul Sănătăţii şi Protecţiei Sociale, Unele probleme privind dinamica sporului natural al populaţiei din Republica Socialistă România (brochure), 1965. Arhiva Ministerului Sănătăţii, fond Cabinet 1, dosar 69/1966, unnumbered.

${ }^{9}$ A.M.S., fond Cabinet 1, dosar 69/1966, unnumbered.
} 
subtitle of the chapter, which read: 'Proposals for measures concerning the improvement of the dynamics of natural population growth'.

Figure 3. Infant mortality dynamics in Romania, 1920-1966

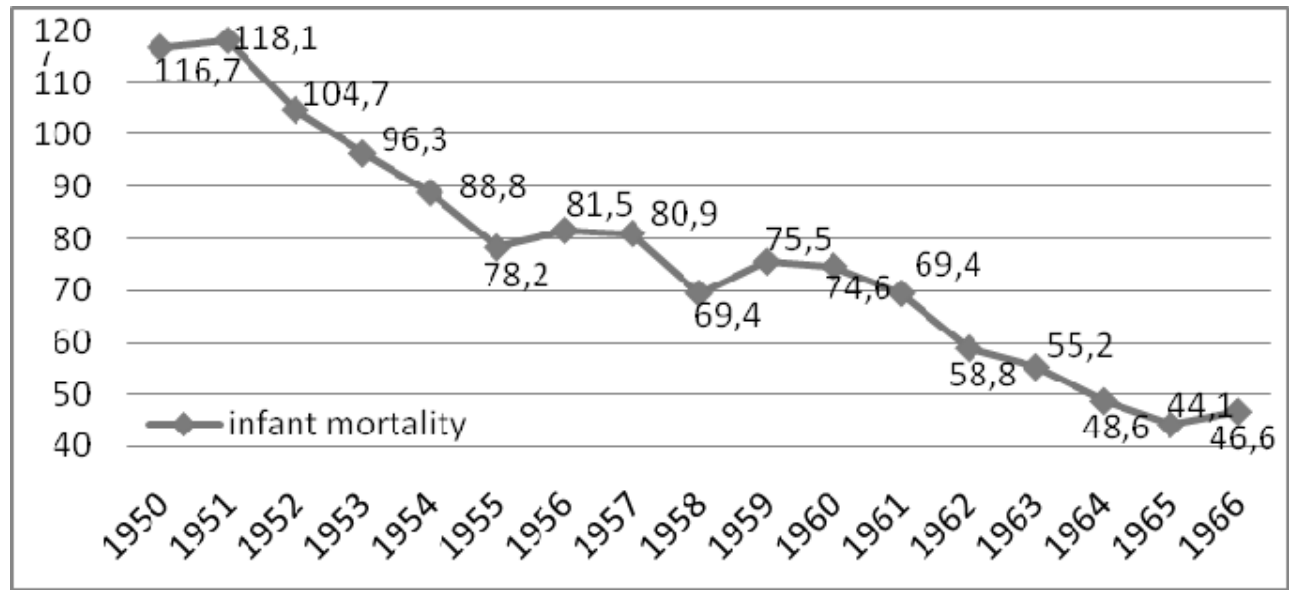

Source: United Nations (1967: 292) for the period 1920-1945, and Muresan (1999: 237-238) for the period 1946-1966

The beginning of the 1960s saw an important rise in the number of requested abortions, from 578,000 in 1959 to $1,115,000$ in $1965 .{ }^{10}$ As infant mortality in this period was in a declining trend (see figure), limiting abortion started to be seen as the solution for increasing birth rates.

The study recommended the setup of a committee of members of the State Committee of Planning, the Ministry of Finance, Health and Social Provisions, Justice, the Committee for Culture and Art, the State Committee for Work and Salaries, the Central Direction of Statistics, the Central Council of Unions, and the National Committee of Women, which would set up a plan of social, economic, and cultural measures for improving the natural growth of the population. The Committee started its work in February 1966 and had the objective of issuing a new report, which would analyse the birth rate in Romania and the measures that could be taken to improve it. ${ }^{11}$

The committee produced two reports: one on 'The healthcare of the Romanian Socialist Republic: methods of improvement', and the other one entitled 'Study concerning the situation of natality in the Romanian Socialist Republic, and the improvement of natality in our country', with an annex on 'The regulation of abortions'. ${ }^{12}$ The second one was more important, as it drew up a plan for the improvement of demographic indicators. The study was finalised and debated in the session of the Executive Political Committee of the Central Committee of the RCP of 2 August 1966. The Study on the situation of natality is of special importance, as it reflects the vision of specialists from the state administration concerning both the existing demographic situation and the measures for improving birth rates.

The first part of this document consists of a demographic study, an overall presentation of the dynamics of the main indicators (natural growth of the population, general and infant mortality, birth rates), of their evolution in the period between 1938 and 1965, and a comparative study of the situation of 26 European states. The authors consider Romanian abortion legislation 'much too permissive'.

\footnotetext{
${ }^{10}$ A.M.S., fond Cabinet 1, dosar 86/1966, unnumbered.

${ }^{11}$ A.N.I.C., fond C.C. al P.C.R., Secţia Cancelarie, dosar 102/1966, f. 23.

${ }^{12}$ A.N.I.C., fond C.C. al P.C.R., Secţia Cancelarie, dosar 101/1966, ff. 102-152.
} 
At that time, the interruption of the natural course of a pregnancy could be made at the request of the pregnant woman without restrictions (anonymously, and without consent from the husband or family members, in the case of minors). Identified as one of the causes of low birth rates, Decree number 463 of $1957^{13}$ is not, however, attacked. It is even justified at times, as an attempt to reduce the number of clandestine abortions in the second half of the 1950s. We can mention the fact that Decree 463 of 1957 was the work of the minister for health, Voinea Marinescu, the same minister who was at the head of the Committee of specialists drafting the above-mentioned study. Criticism of the 1957 legislation would have meant selfincrimination.

For these reasons, the authors of the study proposed 'the introduction of restrictions on requested abortions'. In this way, the technocrats admitted the need to revise Decree 463 of 30 September 1957 in order to introduce stricter procedures. Women who requested abortions had to undergo examination by a specialised committee made up of a gynaecologist, a specialist in internal medicine, and a social worker, who could approve the request only for medical reasons (cases where the foetus or the patient were in danger of disease, genetic factors), or socio-medical reasons (physical and psychological deficiencies, social disapproval, rape, incest). If the applicant was under the age of 16 , the approval of her parents was necessary, and the intervention could be requested also when the woman already had two live children or was over 40 years of age.

According to a proposal of the State Planning Committee and the State Committee for Work and Salaries mentioned in the study, the approval for abortions could be given in regard to the civil state of the woman, her material conditions or geographic location. It has to be mentioned that, among the socio-medical reasons, only rape, incest, post- 45 age, and four children or births will be accepted in the final version, the other suggestions being ignored by the Decree. We may also mention the total exclusion of the post-birth evolution of the mother from the discussion. The possibility the she would benefit from an abortion if she became pregnant in the few months following the birth of a child was not taken into consideration even by specialists. After the application of Decree 770/1966, and not taking into consideration the numerous complaints that doctors filed to the Ministry of Health, even the possibility that these women would receive oral contraceptives was denied. I can also mention here that the administration of oral contraceptives was prohibited even for women who, for medical reasons, could benefit from legal abortions.

The use of contraceptives was considered by the specialists the most appropriate and safe method of family planning. However, their scarce availability on the domestic market, and a lack of proper education for their utilisation, made them inaccessible for the majority of the population. Under these conditions, abortion still remained the most widely spread means of birth control, with negative effects on women's health. In the 1980s, the Minister of Health, Victor Ciobanu, responded to a formal complaint by a gynaecologist concerning the use of contraceptives for women who had medical reasons for abortion: 'Any medical or surgical procedure that suppresses the woman's ability to procreate constitutes a violation of the party's and the state's vision concerning the stimulation of births and is against the law'. ${ }^{14}$

The authorities position concerning contraception oscillated between marginalisation and banning. In 1966, with the start of the pronatalist policies, the problem of contraception was totally marginalised, because of its contradiction with

\footnotetext{
13 'Decretul 463/1957 pentru încuviinţarea întreruperilor de sarcină' (Decree 463/1957 for allowing abortion on request), în Buletinul Oficial al M.A.N. a R.P.R., nr.26 din 30 septembrie 1957.

${ }^{14}$ A.M.S., fond D.A.M.-O.M.C.T., dosar 13/1986, unnumbered.
} 
the main objectives of the policies, but also because of the traditionalist mentality of Nicolae Ceausescu, and other political leaders, who were sceptic about the whole idea of birth control. In this way, the situation of contraception was maintained in an ambiguous state, not being banned, but at the same time, not being permitted. I am referring here to modern methods of contraception only, such as the contraceptive pill, as other mechanical methods, such as condoms, were available in the market during this period, both from domestic production and imported. In the 1980s, Health Ministers prohibited modern contraception altogether.

The study ends with a number of suggestions regarding the measures which could be adopted for solving the problem of the birth rate in Romania. These had a predominantly socio-economic character and projected giving out bonuses for births, an increase in the provision of childcare and the improvement of its functioning, the prolongation of maternity leave, the creation of advantages for employed mothers with respect to pensions, working hours, schedules, medical assistance, and increases in state allowances for children.

The socio-economic measures envisioned by the Committee for the study of measures regarding the improvement of birth rates would be mostly ignored or rejected for political reasons based on the idea that any profoundly pronatalist policy requires a severe restriction of abortions. Because of this, Decree 770 would be fundamentally different from the plan proposed by the Committee, reflecting a more radical vision on abortions.

\section{Session of the Executive Committee of the RCP of 2 August 1966: the political solution ${ }^{15}$}

The session of the Party Executive Committee of 2 August 1966 was important for understanding the vision of the political leadership on the population problem and the way in which demographic indicators could be controlled and regulated. Dogmatism and superficiality, coupled with a pretension of omniscience regarding the issues of such a sensitive domain, all represent major sources of the failure of the pronatalist policy and its negative consequences. As I shall show, the main topic of the session was the issue of abortions, while the stimulation of birth rates through economic measures was marginalised and considered somewhat complementary. This point of view would impose itself in the end and would decisively shape the Romanian policy as restrictive.

An analysis of the discourses of the participants demonstrates the session's nature as a pure formality: the decision was already taken beforehand. With only one exception, that of lon Gheorge Maurer, all positions converge toward the severe curtailment of abortions, the limitation of divorces, the utilisation of propaganda, and the economic stimulation of natality.

The most hard-line speech belongs to Alexandru Draghici, former Minister of the Interior, and head of the Securitate in the 1950s, who vehemently condemned the material put together by the Committee. His line of argument shows a limited, schematic understanding of the problems of the population, and he directly correlates the rise in the number of abortions to the drop in birth rates. His categorical position reads: 'we must at once get rid of this sinful decree, which does nothing but encourage loose morals, and family must remain family'. His position underlined once again the conception of the political leadership up to 1989 on the demographic issue, which consisted on the insistence on the psychological factor (comfort, loose morality) as a source of low birth rates. According to this view, the solution could never be the economic stimulation of the number of births,

\footnotetext{
${ }^{15}$ See A.N.I.C., fond C.C. al P.C.R., Secţia Cancelarie, dosar 102/1966.
} 
but a restriction of abortions and the limitation on the number of divorces. The projected measures should be the most cost-effective as possible. The experience of other European states and their solutions consisting in giving bonuses, stipends, and material aid for families with many children, was considered demagogic: 'This whole study is a cobbling together of foreign experiences, and there is much demagogy in it, especially concerning bonuses, as if the state should buy these children'.

The lengthening of maternity leave and the rise in the provision of childcare were also discarded. The position of the political leadership denoted a lack of proper understanding of the problems involved in raising children. In Romania, maternity leave was set in the 1950s at 112 days, 52 days of prenatal leave and 60 days postnatal leave. In comparison, other socialist states had a much higher number of days, such as the German Democratic Republic, with 182 days (Doboş 2010: 276277; Klinger 1991: 517), Czechoslovakia, 154 days, Hungary, 140 days, Bulgaria, between 120 and 180 days, depending on the number of previous children. ${ }^{16}$ The relatively low number of days for maternity leave was justified by highlighting the need of reintegrating women in production and industry. Virgil Trofin, Secretary of the Central Committee of the RCP, losif Banc, Vice-President of the Council of Ministers, Leonte Rautu, member of the Executive Committee of the CC of the RCP, and Chivu Stoice, President of the State Council, all discussed measures related to the drastic sanctioning of doctors, a substantial rise in fees for abortions and divorces, a sustained propaganda campaign, and the establishment of a differentiated tax for childless persons.

The most balanced position was that of Gheorghe Maurer, the President of the Council of Ministers, who considered the problem to be one of major importance for social evolution, and who was aware that, for its solution, measures would be necessary that went beyond a simple limitation on abortions and divorces. His position is close to that of the specialists from the Ministry of Health. The limitation on abortions, in Maurer's vision, should not be introduced only for the purpose of raising birth rates, 'natality can exist and abortions can influence it very slightly', but to protect the health of women. ${ }^{17}$ He proved himself to be much more cautious than the rest when talking about limiting abortions. Although he declared that 'this law... was a big mistake and must be ended', he highlighted the importance of the way in which the law would be applied, establishing a limit on state involvement in the lives of its citizens: 'after all, the problem of the family is a problem which is solved more and more by the family itself...we must think that we cannot force the family to have more children than it wants to have'.18 The proposed solutions were centred on the modification of the legislation and the need to adopt long term educational programmes.

Nicolae Ceausescu's intervention at the closure of the debate did nothing else but to loosely draw up his demographic vision, which was to be translated into an aggressive population policy in the coming decades. Ceausescu declared himself displeased with the existing situation: "In my opinion, we have legalised prostitution through abortions and free divorces, with this decree... how is this possible, are we an institution for the encouragement of prostitution or do we have the responsibility to keep the health of the people, the natural growth of the people, to defend the morality of the people?... [T] he problem of natality is not a problem of the desires of one to have or not have children, but a social problem, each man has obligations toward society". ${ }^{19}$ This fragment highlights Ceausescu's traditionalist, rural

\footnotetext{
${ }^{16}$ Notă privind legislaţia acordării concediului de maternitate în alte ţări, A.M.S., fond Cabinet 1, dosar 52/1966, unnumbered.

${ }^{17}$ A.N.I.C., fond C.C. al P.C.R. - Cancelarie, dosar 102/1966, f. 17.

${ }^{18}$ A.N.I.C., fond C.C. al P.C.R. - Cancelarie, dosar 102/1966, f. 17.

${ }^{19}$ A.N.I.C., fond C.C. al P.C.R. - Cancelarie, dosar 102/1966, f. 23.
} 
mentality. On the background of a process of state modernisation (the acceleration of industrialisation, the improvement of medical services, the growth of urbanisation) and the dissolution of the religious factor, the traditional family model became implicitly less popular, and new forms of civic behaviour (abortion, divorce, cohabitation) appeared, which were unacceptable to the regime.

In these conditions, the conclusion was as expected: 'I think we must immediately put an end to abortions'. Ceausescu decided that in two weeks time a bill would be presented to regulate the situation of abortions, taking into account the examples of France, the United Kingdom and the United States, and other countries with 'an acceptable level of population growth', and including the presentation of measures designed to drastically sanction those who break the new rules. ${ }^{20}$ It is interesting that the three countries are mentioned not as much for their "acceptable" growth rates, but mainly due to their restrictive abortion legislation. The problem of birth control was absent from the bill, on his indications, 'as it is not current'. In this manner, the objective of raising birth rates at any cost became evident.

\section{The position of medical experts}

As we can surmise, the decision of limiting abortions was taken before the session of the Party Executive Committee on 2 August 1966, the discussions being purely formal and void of content. A political decision needed unanimous support from specialists, which would confer legitimacy to the initiative. To this end, on 20 September 1966, a consultation of the medical establishment took place in the session of the Central Committee of the RCP, dedicated to 'problems regarding the growth of natality and the continuous improvement of the mother and child', with the participation of Ceausescu, Paul Niculescu-Mizil, member of the Political Executive Committee of the RCP, Suzana Gâdea, president of the National Council of Women, Milică Măgureanu, second head of the Health Section of the CC of the RCP, the new Minister of Health, Aurel Moga, and 32 other medical experts, renowned specialists in the fields of gynaecology, obstetrics, paediatrics, pathology, and neurology, as well as regional heads and directors from the Ministry, the majority of those involved in the development of the technocratic option. The purely formal character of the session was highlighted by the quasi unanimity of the opinions expressed by the medical experts in favour of the regulation of abortions. The official reason for the organisation of the session was purely consultative, as Ceausescu reminded even from the outset: 'I insisted on having this consultation in order to discuss together the project for a measure which will appear as a decree regarding the issue of abortion, in medical terms, but which is a consequence of the need to ensuring natality and the growth of our population". ${ }^{21}$

Although the role of the meeting was a purely formal one, that of obtaining legitimacy from specialists for the proposed legislation, there were certain medical specialists that expressed reservations, if not for the measure itself, then for some of its details. The tone was however quite moderate in the confines of the decree itself. No participant disagreed with the severe restriction of abortion, but only with certain provisions of the decree, the most disputed point being that related to the age-limit for abortion.

The attitude of Ion Moraru, Secretary General of the Ministry, was decisive as he stated that all proposed exceptions do nothing but weaken the efficiency of the decree: 'if we introduce many, we reduce the content of this act'. ${ }^{22}$ He stated that

\footnotetext{
${ }^{20}$ A.N.I.C., fond C.C. al P.C.R., Secţia Cancelarie, dosar 101/1966, f. 3.

${ }^{21}$ A.N.I.C., fond C.C. al P.C.R., Secţia Administrativ-Politică, dosar 10/1966.

${ }^{22}$ A.N.I.C., fond C.C. al P.C.R., Secţia Administrativ-Politică, dosar 10/1966., f. 14.
} 
an upper age limit should not be included in the decree due to the fact that the rate of births over the age of 40 is less then 1 percent. Also, abortions below the age of 16 should be considered unacceptable, the solution to such problems being the institutionalisation of such children. The serious physical, psychological or sensorial disability of the pregnant women could not justify an abortion, because 'pregnancy does not harmfully affect disability in the case of a woman who is blind, deaf or mentally disabled'. ${ }^{23}$

The lack of proper housing was not considered to be grounds for a couple not to have children, as 'we all come from households with at least 5-6-7 children, from large families with modest conditions, but in which children could be raised, without child care, without subsidies ${ }^{, 24}$ said Suzana Gâdea, the president of the National Council of Women. This attitude was shared by Ceausescu, who had limited capability for understanding the socio-economic problems of large families, and the major differences related to the raising of children between the urban and rural backgrounds, problems related to living space, security. The large family was, in the past, the traditional, rural, modest family, in which the number of children had an important economic role. Within such an environment, a family with 8 , 9, or even 10 members was common. The members of the family worked a plot of land together, as it was their only resource of existence. The majority of the ruling party elite came from such traditional, large families, from a rural background

The references by Ceausescu to his own experience were a constant: 'I will tell you but one thing, comrades, in the past we did not have better living conditions but the number of births was higher... I have here a letter from Târnăveni from a family which has 13 living children, and the mother gave birth to $17 \ldots$ all these 13 live children, among which a girl who is married and has a child of her own, live in one room... we also were 10 children and lived in one room. ${ }^{, 25}$

The new Minister of Health, Aurel Moga, made a strong declaration: 'we must revise certain formulae in order to disallow any liberalisation and to take as strong as possible measures concerning abortions. ${ }^{26}$

Ceausescu closed the session with a speech that synthesises his positioning, found later in his pronatalist discourse: closing the gap vis-à-vis European countries on the issue of birth rates ${ }^{27}$ the defence of women's health and the defence of morality, the care and responsibility for the human resources of the country. He concluded: '[T] he problem of natality is a duty for each citizen of the motherland, and freedom must be understood in the sense of responsibility that each one has toward the national future. ${ }^{, 28}$ One observation regarding the lack of preparation of the population for the measure of limiting abortion was promptly answered: 'I think the decree is eagerly expected. It is known about for three months. Those who wanted to make preparations for it have made them. On the contrary, among workers, peasants, intellectuals, the decree is quite expected. I feel that certain objections come mostly from the very doctors that occupy these offices (in which abortions take place) and create an unfavourable atmosphere

\footnotetext{
${ }^{23}$ A.N.I.C., fond C.C. al P.C.R., Secţia Administrativ-Politică, dosar 10/1966., f. 14.

${ }^{24}$ A.N.I.C., fond C.C. al P.C.R., Secţia Administrativ-Politică, dosar 10/1966., f. 31.

${ }^{25}$ A.N.I.C., fond C.C. al P.C.R., Secţia Administrativ-Politică, dosar 10/1966., f. 31.

${ }^{26}$ A.N.I.C., fond C.C. al P.C.R., Secţia Administrativ-Politică, dosar 10/1966., f. 38.

${ }^{27}$ The statistic data reveal a sharp decline of birthrate in most of the European countries, thus such a statement in the particular context seems to be unreasonable. In all the talks dealing with the demographic issue, the communist leader always and obsessively brings about the gap between Romania and the other European states in terms of birthrate.

${ }^{28}$ A.N.I.C., fond C.C. al P.C.R., Secţia Administrativ-Politică, dosar 10/1966., f. 40.
} 
towards this measure. But, since their number is small, we shall be able to convince them as well. ${ }^{29}$

Beyond these statements, the goal was clear, and the conclusion of the session reflected the importance and weight of the pronatalist policy as an essential part of the general state development plan: '... we should observe that all the measures we adopt today and will adopt in the future must take into consideration the insurance of the birth rate and the natural growth of the population of our country... all health and social considerations should start from that...,30

In 1966, the only major objective of limiting abortions was the rise of birth rates. The defence of the "morality of the people" and the protection of the health of women are only arguments used to legitimate the restrictive legislation. We must not forget the fact that, after Nicolae Ceausescu came to power in the second half of the 1960s we saw a general process of liberalisation in Romania, the limitation of abortions being somewhat atypical within this trend.

\section{The session of the Executive Committee of the CC of the RCP of 27 September 1966: the adoption of the political alternative}

Protocol 26 of the session of the Executive Committee of the RCP of 2 August 1966 notes the decision to re-work the 'Study concerning the situation of natality in Romania', based on the observations of the session and the two issues, abortion and divorce. The latter were foreseen to become the object of discussion of a special plenary meeting of the Central Committee. ${ }^{31}$ The new material had to consider 'the complex and realistic solution to the problem of birth rate growth', in three main directions, the prioritising the limitation of abortions and the establishment of disciplinary measures for those who 'break the norms of moral behaviour in society', the use of wide-scale propaganda and a complementary measure, the organisation of child care in cities and villages. During the session of 27 September 1966, the final decision on the Decrees 770 and 771 was taken, and they were adopted as they stood.

Decree 770/1966 for the regulation of abortions was much more intransigent when compared to the form proposed by the specialist committee, both in form and content. If, in the first form of the decree, article 1 stated that 'abortions on request can be made only in specialised institutions in cases in which there are medical or socio-medical reasons', the final version read: 'abortions are banned', their use is authorised 'only in exceptional cases', with article 2 enumerating such exceptions: ${ }^{32}$ (a) the pregnancy puts the life of the woman in danger, a danger which cannot be averted by other means; (b) one of the parents suffers from a serious disease, which is hereditary, or which determines severe congenital defects; (c) the pregnant woman is severely disabled physically, psychologically or in a sensorial manner; (d) the woman is over 45 years of age; (e) the woman gave birth to and has four children in her care; ( $f$ ) the pregnancy is the outcome of rape or incest.

Many of these social conditions did not represent exception criteria in the new project for the decree, being admissible only in extreme circumstances. ${ }^{33}$ For

\footnotetext{
${ }^{29}$ A.N.I.C., fond C.C. al P.C.R., Secţia Administrativ-Politică, dosar 10/1966., f. 40.

${ }^{30}$ A.N.I.C., fond C.C. al P.C.R. Administrativ-Politică, dosar 10/1966, f. 39.

${ }^{31}$ A.N.I.C., fond C.C. al P.C.R. Administrativ-Politică, dosar 10/1966, f. 2.

32 'Decret nr. 770/1966 pentru reglementarea întreruperii cursului sarcinii', în Buletinul Oficial al R.S.R., nr. 60 din 1 octombrie 1966

${ }^{33}$ A.N.I.C., fond Consiliul de Stat - Decrete, dosar 770/1966, f. 1.
} 
example, the age limit for a woman seeking abortion grew from 40 to 45 , and the lower age limit of 16 was dropped. If the woman requesting an abortion thought that she fitted into one of the categories outlined above, she could go before a medical committee, appointed by the Executive Committee of the popular councils and chaired by an obstetrician-gynaecologist. ${ }^{34}$ The committee could request specialised clinical examinations, laboratory tests, functional investigations or social inquiries, and in the case the request for an abortion was approved, it chose the location and programmed the surgery, which happened out of working time. In the case in which the abortion was approved, it could be done in the first three months of pregnancy, or in exceptional cases, 'when a serious pathological condition that endangered the life of the woman was ascertained, the period could be extended to six months. ${ }^{35}$

Perhaps the most controversial point of the Decree 770 is the sixth one, which refers to the realisation of abortions in case of emergency. It left room for interpretation regarding the procedures to be applied, as the doctor was the one who had to evaluate if an abortion was provoked or occurred spontaneously. ${ }^{36}$ The doctor was constrained to report the case to the district attorney before the procedure, or if impossible, in 24 hours immediately after, in writing. The attorney then ruled, based on the advice of the coroner and other information available, if the intervention was indeed necessary. If not, the doctor risked being incarcerated for a period up to three months (article 482 of the Penal Code).

During the session of the Executive Committee of 27 September, although he had not previously expressed any of his views, Alexandru Birladeanu, a member of the Executive Committee of the CC of the RCP, and first vice-president of the Council of Ministers, expressed scepticism toward certain aspects of the new legislation. He spoke to the Minister of Health, Aurel Moga, regarding the manner in which the doctor should decide or not to do the abortions in cases of extreme medical urgency and whether the pressure of the prosecutor would not lead the doctor to attempt other methods, putting the life of the woman in danger. ${ }^{37}$ Ceausescu answered this question promptly: 'such cases shall be analysed', while loan Morary placed the entire responsibility on the shoulders of the doctor: 'if the woman dies, the doctor will be accused of manslaughter'. ${ }^{38}$

This latter session was of special significance, due to it being the moment when the decree was finally adopted. The main pronatalist measures, as described above, which represented the political option, were linked to the limitation of abortions, the criminalisation of those responsible, and the limitation of divorces through the complication of divorce procedures. The majority of the elements that were meant to stimulate births socio-economically were dropped. Only those which implied a minimal budgetary effort were retained. The extension of child care represented probably the only substantial measure unanimously accepted, due to its nature of being both pronatalist and supportive of the return of women to work. The number of places in child care was insufficient even in the conditions of total fulfilment of the projected numbers. In 1966, Romania needed 69,000 places, and only had $11,800{ }^{39}$ Up to $1970,6,500$ further places were created, but a large part

\footnotetext{
${ }^{34}$ A.N.I.C., fond C.C. al P.C.R., Secţia Cancelarie, dosar 101/1966, f. 136.

35 'Decret nr. 770/1966 pentru reglementarea întreruperii cursului sarcinii', în Buletinul Oficial al R.S.R., nr. 60 din 1 octombrie 1966

${ }^{36}$ The spontaneous abortion occurs without and exterior interference mainly due to the mother's health condition.

${ }^{37}$ A.N.I.C., fond C.C. al P.C.R., Secţia Cancelarie, dosar 127/1966, f. 22.

${ }^{38}$ A.N.I.C., fond C.C. al P.C.R., Secţia Cancelarie, dosar 127/1966, f. 22

${ }^{39}$ Informare în legătură cu raportul întocmit de Comitetul de Stat al Planificării privind 'Posibilităţi şi soluţii în vederea rezolvării problemei creşelor, A.N.I.C., fond C.C. al P.C.R., secţia Administrativpolitică, dosar 8/1967, f.57.
} 
of these were not the result of constructing new facilities, but overcrowding the existing ones. The other measures did not manage to contribute to the significant improvement of the situation of the families with many children.

When compared with the technocratic plan, the only benefits that stimulated births were: the rise in the number of places in child care, kindergartens and orphanages, special stipends for births and special aid for pregnancy after the third child, the modification of the working schedule for mothers with children under 7 -priority for dayshifts, priority for rest and treatment facilities for families and their children, priority for assignment of homes for families with children and pregnant women after the sixth month, a fee waiver for kindergartens during regular working hours, healthcare for families of unemployed people with at least three children, a revision of the Family Code, the Code for Civil Procedure and the legislation concerning the award of orders and medals for women with many children. ${ }^{40}$

\section{Expenses and finances}

An analysis of state expenditure for pronatalist goals is important in order to understand their essence, which was profoundly simplistic, centred almost exclusively on coercive measures, and in which the stimulation of births had a secondary role, necessary mostly for propagandistic use. In the table below, we may observe the financial costs that were necessary to implement the two plans, the technocratic and the political alternatives, as well as their sources of funding.

Table 1. Budgets of the two alternative pronatalist plans (in million Lei)

\begin{tabular}{|c|c|c|c|}
\hline \multicolumn{2}{|c|}{$\begin{array}{c}\text { Technocratic alternative (version proposed by the } \\
\text { Committee for the study of measures towards } \\
\text { improving the natural growth rate) }\end{array}$} & \multicolumn{2}{|c|}{$\begin{array}{l}\text { Political alternative (revised version following the } \\
\text { meeting from } 2 \text { August 1966) }\end{array}$} \\
\hline \multicolumn{4}{|c|}{ Required Costs (I) } \\
\hline Birth Bonus & 628 & Childbirth allowance & 50 \\
\hline $\begin{array}{l}\text { Increasing the number of } \\
\text { nurseries kindergartens and } \\
\text { orphanages. }\end{array}$ & 25 & $\begin{array}{l}\text { Increasing the number of } \\
\text { nurseries, kindergartens and } \\
\text { orphanages. }\end{array}$ & 19.8 \\
\hline Additional maternity leave & 78 & $\begin{array}{l}\text { Confinement aid for employed } \\
\text { mothers }\end{array}$ & 5.5 \\
\hline $\begin{array}{l}\text { Additional leave for working } \\
\text { mothers }\end{array}$ & 25 & $\begin{array}{c}\text { Free healthcare for mothers with } \\
\text { children from agricultural } \\
\text { cooperatives and non-salaried } \\
\text { families. }\end{array}$ & 17.5 \\
\hline $\begin{array}{l}\text { Child allowance - shift from age } \\
14 \text { to } 15 \text { years }\end{array}$ & 150 & $\begin{array}{c}\text { Expenditures - Rest and treatment } \\
\text { camps for children from families of } \\
\text { employees. }\end{array}$ & 5.3 \\
\hline $\begin{array}{l}\text { Child allowance - granting } 100 \\
\text { for rural workers }\end{array}$ & 140 & & \\
\hline Additional funds for orphans & 30 & & \\
\hline Total & 1,076 & Total & 98.1 \\
\hline \multicolumn{4}{|c|}{ Sources of revenue (II) } \\
\hline Additional tax for employees & 830 & & \\
\hline $\begin{array}{l}\text { Additional tax for cooperative } \\
\text { members }\end{array}$ & 30 & $\begin{array}{l}\text { Increase payroll taxes for } \\
\text { unmarried employees and }\end{array}$ & 210 \\
\hline Increased fee for legal abortions & 75 & childless couples & \\
\hline increase fee for divorce & 15 & & \\
\hline Total & 950 & Total & 210 \\
\hline Difference between II-I & -126 & Difference between II-I & +111.9 \\
\hline
\end{tabular}

The technocratic plan foresaw a total cost of 1,076 million Lei, most of this sum coming from a tax on childless employees, cooperating peasants and increased

\footnotetext{
${ }^{40}$ Hotărârea Comitetului Central al Partidului Comunist Român şi a Consiliului de Miniştri al Republicii Socialiste România cu privire la sprijinirea familiilor cu copii, promovarea natalităţii şi consolidarea familiei. A.N.I.C., Fond C.C. al P.C.R., Secţia Cancelarie, dosar 127/1966, ff. 161-165.
} 
fees from abortions and divorces. The budgetary effort would have been in this case 126 million Lei, which would have had to come from existing budgetary reserves. The sum is considerable since, for example, the total funding for sociocultural actions in 1965 amounted to 8990.8 million, of which only 158 million for social work (Direcţia Centrală de Statistică 1982: 275).

The second approach, the political alternative, foresaw a total expenditure of 98.1 million, ie 977.9 million less than the technocratic plan. It is interesting to note that, after applying the measures meant to stimulate the number of births, the state budget would not suffer, but instead would record a surplus of 111.9 million Lei. This difference was estimated strictly on the basis of the increase of taxation on childless persons, the real sum being much larger, if we add the effect of the increase of the sale prices of alcoholic beverages, tobacco and derivatives from January $1967 .^{41}$

These figures help us identify the sources of the failure of the pronatalist policies of the state, which were made up of poor information on the real needs of families and centred on the direct needs of the state, in a system which constrains to obtain. In the case of Romania, the approach of the problem of birth rates was a profoundly ideological one, based on a traditionalist ideology, together with communist principles, which took on the shape of national Stalinism. The demographic strategy implemented in Romania after 1966 does not contain original elements, as each piece of the pronatalist policy had its counterpart in the Stalinist plan of 1936 . The benefits granted were great in number, but substantially insignificant. Under these conditions, propaganda tended to overestimate the benefits offered by the state, and underplay the coercive measures, which were presented as a show of concern of the party toward the health of the people.

\section{Conclusion}

On the basis of the documents analysed in the article we can distinguish between the need to adopt a pronatalist policy in itself, and the restrictive manner in which it was done. If, for the first question, the entire argumentation based on economic, political-ideological, and moral aspects was valid, for the second question, the policy choice was determined by the need to obtain quick results with a minimal economic cost.

The debate within the Executive Committee of the RCP around the two policy alternatives, namely the political option consisting in the imposition of a strict ban on abortion, and the technocratic alternative resulting from consultations with specialist medical staff, was purely formal. The character of the policy adopted was decisively influenced by the political desire to achieve higher birth rates. The minutes of these sessions show a lack of a real debate on the set of pronatalist measures to be adopted. The restrictive and unpopular measures that finally carried their way only needed to be legitimated at that time. Essentially, in 1966, the Communist state did not show any interest in promoting births through economic incentives.

In this paper I have presented an analysis of the budgetary cost of the two alternative approaches to the growth of birth rates. This comparative exercise undertaken by the government at the time when the 1966 Decree was being debated points in the direction that the budgetary constraint was a deciding factor in favour of the political alternative based on a strict ban on abortion. The political plan projected a total expenditure of 98.1 million Lei, ie 977.9 million less than the technocratic plan. The projected costs of the political option were to be entirely covered by the revenue from taxes imposed on childless employees. Thus, the

${ }^{41}$ A.N.I.C., fond C.C. al P.C.R., Secţia Cancelarie, dosar 127/1966, f. 164. 
regime focused on the propagandistic role of the measures, permanently present in the communist media, rather than on their direct effect on birth rates.

The regulation of abortions represented, during the 23 years of application of the Decree 770/1966, the central element of Ceausescu's pronatalist policy, and the one which gave his population policy its overall restrictive character. After 1966, Romania singled itself out among the states of the Socialist bloc, but even among the states of Europe, as one of the states with the most severe population policy. The uniqueness of the Romanian case is not due to the restriction of abortion, but the severity of the measure, via the imposition of a strict filter of medical and social exceptions, and, moreover, by the limitation, marginalisation, in a direct and indirect way, of modern contraception and sexual education as a means of family planning. All these aspects are unusual because Romania had traversed a period of almost a decade of liberalisation concerning abortions. The entire vision on the growth of births is anachronistic. When the general European tendency was one of liberalisation, Romania returned to the Stalinist model of the 1930s.

\section{References}

Anton, Lorena (2007) 'Abortion during Communist Romania: from its official History and its Memory', in Catherine Baker, Christopher J. Gerry, Barbara Madaj, Liz Mellish, Jana Nahodilová (eds.), Nation in Formation: Inclusion and Exclusion in Central \& Eastern Europe. London: UCL-SSEES, pp. 177-195.

Anton, Lorena (2009) 'Abortion and the making of the socialist mother during Communist Romania', in Lisa Bernstein, Pamela Monaco (eds.), (M)Othering the Nation: Constructing and Resisting Regional and National Allegories Through the Maternal Body. Cambridge: Cambridge Scholars Press, pp. 49-61.

Baban, Adriana (1999) "Romania' in H. P. David (ed.) From abortion to contraception. A resource to public policies and reproductive behavior in Central and Eastern Europe from 1917 to the present. London: Greenwood Press, pp. 191222.

Baban, Adriana (2000) 'Women's sexuality and reproductive behavior in postCeausescu Romania: a psychological approach' in Susan Gal and Gail Kligman (eds.) Reproducing gender. Politics, publics, and everyday life under socialism. Princeton: Princeton University Press, pp. 225-256.

Bărbulescu, Elena (1998) 'Femeia şi avortul în perioada 1966-1989', Anuarul de Istorie Orală 1: 177-193.

Betea, Lavinia (2004) 'Interzicerea avorturilor (1966-1989) ca fapt de memorie socială' ['Forbidden abortions in the social memory (1966-1989)'], in Adrian Neculau (ed.) Viaţa cotidiană în communism. Iaşi: Polirom.

Betea, Lavinia (2011) I se spunea Machiavelli. Ştefan Andrei în dialog cu Lavinia Betea. Bucureşti: Adevărul Holding.

Bodeanu, Denisa Florentina (2002) 'Politica demografică a regimului comunist reflectată în revista „Femeia” (1966-1989)', in Ghizela Cozma, Virgiliu Târău (eds.) Condiţia femeii în România în secolul XX [The condition of women in Romania in the twentieth century], vol. II. Cluj-Napoca: Presa Universitară Clujeană.

Ceausescu, Nicolae (1970) România pe drumul construirii societăţii socialiste multilateraldezvoltate, vol. 4. Bucureşti: Editura Politică.

Ceausescu, Nicolae (1981) Populaţia şi forţa de muncă. Bucureşti: Editura Politică.

Cioroianu, Adrian (2012) 'Ceauşescu, decretul 770/1966 şi generaţia „decreţeilor”. Generaţia şi decretul care au schimbat România', URL (consulted Jan. 2013): http://geopolitikon.wordpress.com.

Direcţia Centrală de Statistică (1982) Anuarul statistic al R.S.R. 1982. 
Doboş Corina, Luciana M. Jinga and Florin S. Soare (eds.) (2010) Politica Pronatalistă a regimului Ceauşescu 1966-1989. O perspectivă comparativa. Iaşi: Polirom.

Fischer, Mary Ellen (1985) 'Women in Romanian politics: Elena Ceauşescu, pronatalism and promotion of women', in Sharon Wolchik and Alfred Meyer (eds.) Women, State and Party in Eastern Europe. Durham: Duke University Press.

Goldman, Wendy Z. (1993) Women, the State and Revolution. Soviet Family Policy and Social Life, 1917-1936. Cambridge: Cambridge University Press.

Hord, Charlotte, Henry P. David, France Donnay and Meril Wolf (1991) 'Reproductive health in Romania: Reversing the Ceauşescu Legacy', Studies in Family Planning 22(4): 231-240.

Jinga, Luciana M. and Florin S. Soare (eds.), Corina Doboş and Cristina Roman (2011) Politica Pronatalistă a regimului Ceauşescu 1966-1989. Instituţii şi practici. laşi: Polirom.

Johnson, Brooke, Mihai Horga and Laurenţia Andronache (1991) 'Contraception and abortion în Romania', Lancet 341: 231-240.

Kivu, Mircea (1993) 'Une retrospective: la politique demographique en Roumanie 1945-1989', Annales de demographie historique: 107-125.

Kligman, Gail (1992) 'When Abortion is Banned: The Politics of Reproduction în Ceauşescu's Romania, and After, National Council for Soviet and East European Research', URL (consulted Jan. 2013): http://www.ucis.pitt.edu/nceeer/1992-80514-Kligman.pdf.

Kligman, Gail (1998) The Politics of Duplicity: Controlling Reproduction in Ceausescu's Romania. Berkeley, Los Angeles and London: University of California Press.

Klinger, Andràs (1991) 'Les politiques familiales en Europe de l'Est', Population 46(3): 511-526.

Mclntosh, Alison C. (1983) Population Policy in Western Europe: Responses to Low Fertility in France, Sweden, and West Germany. Armonk, New York: M.E. Sharpe.

Mureşan, Cornelia (1999) Evoluţia demografică a României. Tendinţe vechi, schimbări recente, perspective (1870-2030). Cluj-Napoca: Editura Presa Universitară Clujeană.

Pavelescu, Ion (1977) 25 de milioane. Populaţia - sursă a dinamismului economico-social. Bucureşti: Editura Politică.

Pălăşan, Corina (2009) 'Caracterul profund restrictiv al politicii nataliste româneşti', in Ruxandra Ivan (ed.) Transformarea socialistă. Politici ale regimului comunist între ideologie şi administraţie. Iaşi: Editura Polirom.

Partidul Comunist Roman (1975) Programul Partidului Comunist Român de făurire a societăţii socialiste multilateral dezvoltate si înaintare a României spre communism. Bucureşti: Editura Politică.

Pop-Eleches, Cristian (2006) The Impact of an Abortion Ban on Socioeconomic Outcomes of Children: Evidence from Romania, Journal of Political Economy 114(4): 744-773.

Pop-Eleches, Cristian, (2004) 'The Supply of Birth Control Methods, Education and Fertility: Evidence from Romania', Journal of Human Resources 45(4): 971-997.

Popescu, Dumitru, (1993) Un fost lider comunist se destăinuie. Am fost şi cioplitor de himere Convorbire realizată cu Ion Tecşa, ziarist. Bucureşti: Editura Expres. 
Retegan, Mihai (2002) Război politic în blocul comunist. Relaţii româno-sovietice în anii şaizeci. Bucureşti: Editura Rao.

Şerbănescu, Florina, Leo Morris, Paul Stupp and Alin Stănescu (1995) 'The Impact of Recent Policy Changes on Fertility, Abortion, and Contraceptive Use in Romania', Studies in Family Planning 26(2): 76-87.

Trebici, Vladimir (1971) Populaţia României şi creşterea economică, studii de demografie economică. Bucureşti: Editura Politică.

Trebici, Vladimir (1981) 'La transition demographique dans la pays de l'Europe de l'Est: le cas de la Roumanie', Atti del seminario su La transitione demografica. Interrelazioni tra sviluppo demografico e sviluppo economico, Società italiana d'economia demografica e statistica.

United Nations (1967) Demographic Yearbook, Incl. Special Topic: Mortality Statistics II. New York: United Nations. 